\title{
Mali Disiplin Ve Enflasyon İlişkisi Üzerine Bir Analiz: Türkiye Örneği
}

\author{
Suat Hayri ŞENTÜRK ${ }^{1}$ \\ Birol KARAKURT ${ }^{2}$ \\ Burak ŞAHINGÖZ ${ }^{3}$
}

ÖZ: Türkiye'de 1980 sonrasında bozulan mali dengeleri (bütçe dengesi, kamu borç stoku) sağlamlaştırmak için, 1994 yllından sonra mali disiplini sağlamak önemli bir politika haline gelmiştir. Bu çalışmada, uygulanan mali disiplin politikalarının enflasyon ile etkileşimi incelenmektedir. 1980-2016 yıllık verilerinin kullanıldiğı araştırmada, enflasyon ile bütçe dengesi, faiz dışı bütçe dengesi ve kamu borç stoku arasındaki ilişkiler Toda-Yamamoto nedensellik testi, etki-tepki fonksiyonu analizleri ile ele alınmıştır. Ampirik bulgulara göre, bütçe açı̆̆ındaki artı̧s enflasyonu arttırırken, faiz dışı fazla verilmesi enflasyonda düşüse neden olmaktadır. Kamu borç stokundaki artış ise kısa dönemde enflasyonu azaltıcı yönde bir etki meydana getirmektedir.

Anahtar Kelimeler: Mali Disiplin, Bütçe Açı̆̆ı, Enflasyon, Toda-Yamamoto Nedensellik Testi

Jel Kodu: E62, H62, H63

\section{An Analysis on Fiscal Discipline and Inflation: The Case of Turkey}

\begin{abstract}
Ensuring fiscal discipline has become an important policy after 1994 in order to stabilize fiscal balances (budget balances, public debt) that deteriorated in Turkey after 1980. The interaction of applied fiscal discipline policies with inflation has been examined in this study. The relationship between inflation and budget balance, primary balance and public debt stock has been examined by using the Todo-Yamamoto causality test, impulse-response analyzes based on the period of 1980-2016 annual data. According to empirical findings, while an increase in budget deficit causes inflation to raise, primary surplus leads to a decrease in inflation. An increase in public debt stock has a reducing effect on inflation in the short run.
\end{abstract}

Key Words: Fiscal Dicipline, Budget Deficit, Inflation, Toda-Yamamoto Causality Test

Jel Codes: E62, H62, H63

Geliş Tarihi / Received: 29/09/2017

Kabul Tarihi / Accepted: 16/10/2017

\footnotetext{
1 Doç. Dr., Gümüşhane Üniversitesi, İ̈BF, Maliye Bölümü, suathayrisenturk@yahoo.com, orcid.org/0000-0003-2930-8888.

2 Prof. Dr., Karadeniz Teknik Üniversitesi, İ̈BF, Maliye Bölümü, birolkarakurt@yahoo.com, orcid.org/0000-0002-6325-2171.

3 Arş. Gör., Karadeniz Teknik Üniversitesi, İIBB, Maliye Bölümü, buraksahingoz@windowslive.com, orcid.org/0000-0002-4179-1609
} 


\section{Giriș}

Klasik iktisadi düşünce bütçe açı̆̆ı ve fazlasına karşıdır. Fakat klasik iktisadi düşüncenin önemini yitirdiği 1929 Büyük Buhranı sonrası egemen olan Keynesyen iktisadi düşünceyle birlikte, bütçenin dönemsel olarak açık vermesinin kötü olmadığ 1 ve içinde bulunulan buhrandan çıkış için (talep daralmasına karşılık) kamu harcamalarının arttırılabileceği ve bütçe açıklarının göz ardı edilebileceği (istikrarsızlıkların kaynağı olmadığı) bir iktisadi anlayış (maliye politikası bakışı) ön plana çıkmıştır. Keynesyen anlayışın talep krizine (dolayısıyla üretim) cevap olarak ortaya koyduğu kamu harcamalarının artırılması ve böylelikle istikrarsızlık ve işsizliğin önlenmesi düşüncesi stagflasyon olgusu ve krizler dolayısıyla gerçekleşmemiş ve Keynesyen düşüncenin de sorgulanmasına neden olmuștur. Nitekim 1980'li yıllara gelindiğinde gelișmiș ve gelișmekte olan birçok ülkenin mali dengeleri olumsuz bir tablo göstermiştir. Bu nedenle 1980'li yıllarda devletin ekonomideki payını ve fonksiyonlarını sorgulayan neo-liberal yaklaşım ve bu yaklaşımın önerisi olan mali disiplinin sağlanması önem kazanmıştır.

Mali disiplinin en temel tanımı bütçe denkliği ile ifade edilmektedir. Ancak geçmişte ortaya çıkan bütçe açıkları, yüksek borç stokları ve bu borçlardan kaynaklanan faiz ödemeleri ülkelerde denk bütçenin sağlanmasını zorlaştırmıştır. $\mathrm{Bu}$ nedenle mali disiplini sağlamak, sadece bütçede denkliğin elde edilmesi anlamından çıkarak daha esnek hale gelmiştir. Günümüzde mali disiplin kavramı en geniş şekli ile sürdürülebilir bir borç seviyesinin ve ölçülü bir bütçe açığının sağlanması olarak ifade edilmektedir (Hemming, 2003: 2).

Mali disiplinin sağlanmasına ilişkin olarak farklı yaklaşımlar ortaya konulmuştur. Söz konusu yaklaşımlar doğrultusunda mali disiplinin sağlanabilmesi için ilk olarak bütçe kapsamının genişletilmesi, kamu gelir ve giderlerinin olabildiğince bütçe kapsamı içinde olmasının sağlanması gerekir. İkinci olarak, neo-klasik düşüncenin de vurguladığı kamu harcamalarının azaltılması ile ilgili uygulamalardan söz edilebilir. Üçüncü olarak, kamu gelirlerinin artırılmasına yönelik önlemler karşımıza çıkmaktadır. Bu çerçevede, neo-klasik yaklaşım (özellikle de Arthur Laffer) vergi oranlarının azaltılması neticesinde vergi gelirlerinin arttırılabileceğini savunmaktadır. Son olarak ise, mali disiplin için borç stokundaki büyüklüğe (borç seviyesine) dikkat çekilmektedir. Yüksek borç stokunun yüksek maliyetlere neden olması mali disiplinin sağlanmasını zorlaştırmaktadır. Bu nedenle doğru bir borç yönetiminin varlığı mali disiplini sağlamada önemli bir yaklaşım olarak değerlendirilmektedir (Ejder, 2006: 27-40). İlave olarak, (Molnar, 2012: 13) mali disiplini sağlamada bütçe açıklarının boyutuna vurgu yaparken, (Barrios ve diğerleri, 2010: 15) ise yüksek borç stokunu, ülkeleri mali disiplini sağlamaya zorlayan önemli bir gösterge olarak ifade etmektedir. Ayrıca, literatürde, faiz dışı bütçe dengesinde fazla verilmesi önemli bir mali disiplin göstergesi olarak karşımıza çıkmaktadır (Tsibouris ve diğerleri, 2006; Susam, 2009; Çoban, 2015). Bu nedenle, çalışma kapsamında 
mali disiplin göstergesi olarak bütçe dengesi, borç stoku ve faiz dış1 bütçe dengesi kullanılmıştır.

Türkiye'de mali dengelerdeki bozulma kendisini 1980'li yıllarda göstermiştir. 1980 istikrar kararlarında, bütçe açığının ve kamu borç seviyesinin azaltılmasına vurgu vardır. Fakat mali göstergelerdeki esas bozulma 1990'lı yıllarda ortaya çıkmış ve hem bütçe açığı hem de kamu borç seviyesi GSYH oranı \% 10'ları aşmıştır. Nitekim, ekonomide tekrardan istikrarı tesis etmek için uygulanan 5 Nisan 1994 istikrar tedbirleri faiz dışı fazla verilerek mali disiplinin sağlanmasına ve enflasyonun kontrol edilmesine odaklanan bir istikrar programıdır. Gerek o günün siyasi iklimi, gerekse istikrar programına kamuoyu desteği ve uygulayıcıların programı takip etmedeki kararsızlığı bütçe açığının ve borç seviyesinin kontrol edilmesini mümkün kılmamıştır. 2000'li yıllarda ise, ülkenin yaşadığı en büyük kriz neticesinde, mali disiplinin sağlanması ve enflasyonun kontrol edilmesi ve ekonominin yeniden büyüme periyoduna geçişinin sağlanması ülke açısından kaçınılmaz son olmuştur. Bu kapsamda uygulamaya konulan, 14 Nisan Güçlü Ekonomiye Geçiş Programı'nın mali disiplinin sağlanması noktasında en temel dayanak noktası faiz dışı fazla vererek bütçe açığııı, borç seviyesini ve dolayısıyla enflasyonu kontrol etmek olmuştur.

Mali disiplini sağlamaya dönük politikaların, esasen de, maliye politikası uygulamalarının sürdürülebilir mali yapıyı temin etmesi hedeflenir. Bu çerçevede; bütçe kapsamının genişletilmesi, kamu harcamalarının azaltılması, kamu gelirlerinin artırılması ve doğru bir borç yönetiminin yapılması neticesinde; bütçe açıklarının azalması, borçların sürdürülebilir hale gelmesi ve faiz dışı dengede fazla verilmesi beklenir. Ancak daraltıcı maliye politikalarının başarılı bir şekilde uygulanması sonucunda enflasyonun hangi yönde şekilleneceği literatürde tartışmalı bir konu olarak karşımıza çıkmaktadır.

Çalışma kapsamında, Türkiye ekonomisinde bütçe dengesi, faiz dışı bütçe dengesi ve kamu borç stokunun enflasyonla ilişkisini tespit etmek amaçlanmıştır. Bu kapsamda öncelikle birinci kısımda mali disiplin arayışı ve enflasyon ilişkisi üzerinde durulmuştur. İkinci bölümde literatür taraması yapılmıştır. Üçüncü bölümde analizde kullanılan değişkenler tanıtılmış, durağanlık testleri yapılmış ve Toda-Yamamoto (1995) nedensellik testi ile Etki-Tepki fonksiyon analizinden faydalanılmıştır. Çalışmanın literatürden farkı, birinci olarak mali disiplin enflasyon etkileşiminin daha geniş bir zaman periyodunda analizine imkan vermesidir. İkinci olarak mali disiplin göstergesi olarak literatürde genellikle bir veya iki (bütçe açığı, yada bütçe açığı ile birlikte borç stoku/seviyesi) değişkenli modellerin çözümlemesi şeklindedir, çalışmada ise mali disiplin göstergeleri çoğaltılarak model çözümlemeleri yapılmıştır. Üçüncü olarak da, literatürde enflasyon ile nedensellik ilişkisi genellikle Granger nedensellik testi ile analiz edilmiştir. Sınırlı sayıda çalışmada, bütçe açığı ve enflasyon arasındaki ilişki Toda-Yamamoto (1995) nedensellik testi ile analiz edilmiştir. Çalışmada ise, mali 
disiplinin diğer unsurları ile enflasyon arasındaki nedensellik ilişkisi de TodoYamamoto nedensellik testi ile analiz edilmiştir.

\section{Literatür}

Teoride maliye politikalarının enflasyon üzerindeki etkisi tartışmalı bir konudur. Bütçe dengesindeki değişimin enflasyon üzerindeki etkisi kamu harcamalarındaki değişim, kamu gelirlerindeki değişim ve bütçe açık veriyorsa açıklarının nasıl finanse edildiğine bağlıdır. Borçlanmadaki değişimin enflasyon üzerindeki etkisi ise borçlanmanın nasıl finanse edildiğine ve faiz giderlerinin maliyetine bağlı olarak değişmektedir.

Kamu harcamalarını azaltmaya yönelik mali disiplin politikaları, toplam talebi azalttığı ve piyasaya mali disipline bağlı kalınacağına dair güçlü sinyaller verdiği için fiyat istikrarının sağlanmasında güçlü bir araç olarak kullanılmaktadır. Ayrıca, vergi gelirlerini arttırarak mali disiplin sağlama çabaları da enflasyonu baskı altına almada etkili bir araç olarak kullanılmaktadır (Leigh ve diğerleri, 2010: 93). Bu bağlamda, enflasyondaki değişimin sadece maliye politikaları ile açıklanması mümkün değildir. Uygulanan maliye ve para politikalarının uyum içinde olması bu açıdan önemlidir. Literatürde mali disiplin politikaları ile enflasyon arasındaki ilişki araştırılırken enflasyon oranındaki değişimin asıl belirleyeni para ve maliye politikalarındaki koordinasyon olarak karşımıza çıkar. Mali disiplin politikalarının başarılı bir şekilde uygulanması sonucunda beklenen etki ise piyasada talebin kısılması ve enflasyonun düşüş göstermesidir.

Çalışma kapsamında sadece maliye politikası araçlarının (veya mali disiplin unsurlarının) enflasyon ile etkileşimi araştırılmıştır. Literatürde, bütçe dengesi, borçlanma ve faiz dişı dengenin enflasyon ile etkileşimini inceleyen birçok ampirik çalışma bulunmaktadır. Konuyla ilgili ampirik çalışmalar, hem etkileşimin yönünü anlamak açısından hem de ilişkinin var olup olmadığını anlamak açısından önemlidir.

Mali disiplin unsurları ile enflasyon arasındaki ilişkiyi ele alan çalışmalarda, mali disiplinin olmayışı (bütçe açığı ve artan borç seviyesi) enflasyonist midir sorusunun cevabı geleneksel teorik literatür için (para politikası otoriteleri açısından) kesinlikle evettir. Fakat amprik literatürden elde edilen bulgular kesinlik belirtmez, olabileceğini ifade eder (Vieria, 2000). Greenspan'de (1995) Kansas merkez bankasının düzenlediği sempozyumda, bütçe açı̆̆ı ve borç seviyesinin ekonomik sonuçlarına ilişkin yaptığı konuşmada, kronik bütçe açıkları ve yüksek borç seviyesinin büyümeyi olumsuz etkilediğini belirtmiştir. İlave olarak da, pek çok uzun dönemli mali dengesizliğin Amerikan mali sisteminden uzaklaştırılması gerektiğini ve çoğu merkez bankacısının Amerika'da uzun dönemde bütçe açığında yapılacak esaslı bir indirimin (mali disiplinin) diğer ülkelerle kıyaslandığında uzun dönem enflasyon perspektifinde düşüşe yol açacağını tahmin ettiğini ifade etmiştir. Avrupa Konseyi de, hükümetin mali yapısının sağlam olmasının öneminin fiyat istikrarı amacını güçlendirmeye 
yardım edeceğine vurgu yapmaktadır (European Council on the Stability and Growth Pact, 1997).

Mali dengelerdeki değişimin enflasyonla etkileşimini ekonometrik olarak analiz eden öncü çalışma ise Sargent ve Wallace (1981) aittir. Çalışmalarında, sıkı para politikasının uygulandığı bir ekonomide, kamu borçlanması yoluyla bütçe açıklarının finansmanının uzun dönemde enflasyonda artışa neden olacağını ifade etmişlerdir. Literatürde öncü çalışmalar arasında yer alan "bütçe açığını büyüten harcamalar, para ve enflasyon" olarak ifade edilebilecek olan çalışmada (Giannaros ve Kolluri, 1985), para arzı ve enflasyondan oluşan iki denklemli ekonometrik model geliştirmiş ve tahmin etmişlerdir. Sonuçlara dayanarak, genel olarak, bütçe açığının para arzı veya enflasyon artışının doğrudan veya dolaylı olarak nedeni olmadığını ifade etmişlerdir.

Literatürde mali disiplin unsurlarının (bütçe açığı veya borç seviyesi) enflasyon ile ilişkisi tek veya birlikte farklı ülkeler ve dönemler için analize tabi tutulmuştur. $\mathrm{Bu}$ çerçevede, Catao ve Terrones (2005), 107 ülkeden aldıkları veriler ile mali açıkların enflasyonist etkilerini araştırdıkları çalışmada panel veri tekniği ile değişkenler arasında uzun ve kısa dönemli ilişkiyi analiz etmişlerdir. 1960-2001 verilerinin kullanıldığı çalışmada, enflasyon ve mali açıklar arasında doğrusal olmayan ilişki modellenmiştir. Ampirik bulgulara göre, gelişmekte olan ve yüksek enflasyona sahip ülkelerde enflasyon ile mali açıklar arasında güçlü ve pozitif yönlü ilişki tespit edilirken gelişmiş ve düşük enflasyona sahip ülkelerde ilişki tespit edilmemiştir.

Mali disiplinin makroekonomik değişkenler üzerindeki etkisini analiz etmek amaciyla Grambsh-Therneau testi kullanan Tsibouris ve diğerleri (2006) ise, 1971-2001 dönemi verilerini kullandıkları çalışmalarında, 165 ülkeden faiz dış1 bütçe fazlası yüzde 5 ve üzeri olan 300 gözlem kullanmışlardır. Bulgulara göre, faiz dışı bütçe fazlası toplam talebi olumsuz etkilemektedir. Yatırım harcamalarını azaltarak verilen faiz dişı bütçe fazlası ise büyümeyi olumsuz yönde etkilemektedir. Mali disiplin uygulamaları enflasyonu dizginlemede etkili olurken sürdürülebilir borç seviyesine ulaşılmasına katkı sağlamaktadır.

Kumar ve diğerleri (2007) ise, mali disiplin ile büyüme, çıktı açı̆̆ı, işsizlik ve enflasyon arasındaki etkileşimi analiz etmek amacıyla GIMF (Global Integrated Monetary and Fiscal) modelini kullanmışlardır. 1990-2000 dönemi verileri 24 OECD ülkesinden elde edilmiştir. Ampirik bulgulara göre, kısa dönemde mali disiplin uygulamaları ekonomik büyümeyi olumlu etkilerken uzun dönemde pozitif yönde etkilere sebep olmaktadır. Faiz dışı bütçe fazlasındaki artış enflasyon oranını ve faiz oranlarını azaltmaktadır. Çıktı açı̆̆ı ile istatiksel olarak anlamlı bir sonuca ulaşılamamıştır. Mali disiplin sağlama çabalarının makroekonomik etkileri analiz etmek amacıyla 14 ülkeden elde edilen verilerle GIMF modelini kullanan Leigh ve diğerleri (2010)'nin çalışmalarının ampirik bulgulara göre, kısa dönemde mali disiplinin büyümeyi azalttığı ve işsizliği arttırdığı sonuçlarına ulaşılmıştır. Çalışmada mali disiplinin faiz oranlarını 
düşürdüğü ve dolaylı vergilerin arttırılması şeklinde uygulanan mali disiplin politikalarının enflasyonu arttırdığına ilişkin bulgular edinilmiştir.

1970-2005 yıllık verilerini kullanarak Nijerya için bütçe açıkları ile enflasyon oranı arasındaki nedensellik ilişsisini Granger nedensellik testinden yararlanarak analiz eden Oladipo ve Akinbobola (2011), bütçe açıklarından enflasyon oranına tek yönlü nedensellik ilişkisi tespit etmişlerdir. Çalışmada bütçe açıklarının enflasyonu doğrudan etkileyebileceği gibi döviz kurundaki dalgalanmalar yoluyla dolaylı olarak da etkileyebileceği bulgusuna da ulaşılmıştır.

ABD'de kamu borç stokunun faiz dişı bütçe dengesi, enflasyon ve ekonomik büyümeye verilen bir şok karşısındaki tepkisini VAR modeli yardımıyla elde edilen etki-tepki analizi ile araştıran Cherif ve Hasanov'un (2012) elde ettiği bulgulara göre, enflasyon oranına verilen bir birimlik şok karşısında kamu borç stoku birkaç dönem negatif tepki verirken daha sonrasında ise pozitif tepki vermektedir. Para politikasından farklı tepkiler beklenmediği sürece borç stoku enflasyon şokları ile azaltılabilir. Daha az faiz artırımı yapan daha az müdahaleci para politikasıyla enflasyon şoku kamu borç stoku oranını azaltmada önemli bir rol oynayabilir.

Nguyen (2015) ise seçilmiş bazı Asya ülkelerinde (Bangladeş, Kamboçya, Endonezya, Malezya, Pakistan, Filipinler, Sri Lanka, Tayland ve Vietnam) mali açıklar ile M2 para arzının enflasyon üzerindeki etkisini analiz etmiştir. 19852012 dönemi verilerinin kullanıldığı çalışmada Westerlund panel eş-bütünleşme testi ve Pooled Mean Group (PMG) hata terimi modelinden yararlanılmıştır. Westerlund panel eş-bütünleşme sonuçlarına göre, enflasyon ile mali açıklar ve M2 para arzı arasında eş-bütünleşme ilişkisi tespit edilmiştir. PMG hata terimi modeli sonuçlarına göre ise mali açık, kamu harcamaları ve faiz oranı uzun dönemde enflasyonu \%1 anlamlılık düzeyinde pozitif etkilerken M2 para arz1 $\% 10$ anlamlılık düzeyinde etkilemektedir. Sonuçlara göre, mali açık ve kamu harcamaları enflasyonu etkileyen iki önemli politika aracı olarak belirtilmektedir.

Yien ve diğerleri (2017) Malezya'da enflasyon, dış borç, iç borç ve döviz kuru arasındaki ilişskiyi tespit etmek için Johansen eş-bütünleşme testi ve Granger nedensellik testinden yararlanmışlardır. 1960-2014 dönemi verilerinin kullanıldığ1 araştırma bulgularına göre, enflasyon iç borcun granger nedeni, döviz kuru enflasyonun granger nedeni ve diş borç döviz kurunun granger nedeni olduğu sonuçlarına ulaşılmıştır. Kısa dönemde diş borç enflasyonu önemli derecede etkilerken uzun dönemde döviz kuru enflasyonu etkilemektedir.

Bütçe açığı, borç seviyesi ve faiz dışı bütçe dengesi (mali disiplin unsurları) ile enflasyon arasında oldukça zengin bir literatür vardır. Fakat Türkiye üzerine mali disiplin unsurları (özellikle faiz dışı bütçe fazlası ve kamu borç stoku) ve enflasyon ilişkisini analiz eden çalışma sayısı sınırlıdır. Bu konuda, Metin'in (1998), enflasyon ile bütçe açığı arasındaki ilişkiyi Türkiye açısından çok değişkenli eş bütünleşme testi kullanarak ilişkiyi analiz ettiği çalışma öncü (İpek 
ve Akar, 2016:170) çalışmadır. Metin (1998), 1950-1987 y1llık verilerinin kullanıldığı çalışmada, tek denklem model sonuçlarına göre borçların monetizasyonuna ek olarak büyük çaplı bütçe açıklarının enflasyonu önemli derecede etkilediği sonuçlarına ulaşmıştır.

1994:01-2003:11 aylık verilerinin kullanarak kamu iç borçları, enflasyon, faiz oranları ve sanayi üretimi arasındaki ilişkiyi analiz etmek amacıyla JohansenJuseluis eş bütünleşme ve Granger nedensellik testlerini kullanan Kalaycı ve diğerleri (2004), eş bütünleşme testine göre değişkenler arası uzun dönem ilişki bulamamışlardır. Granger nedensellik testi sonuçlarına göre ise kamu iç borçlarından enflasyona, enflasyondan faiz oranlarına ve faiz oranlarından kamu iç borçlarına tek yönlü nedensellik ilişkisi tespit edilmiştir. Demir ve Sever (2008), kamu iç borçlarının büyüme, faiz oranları ve enflasyon üzerindeki uzun dönemli etkisini Johansen eş-bütünleşme testi, kısa dönemli etkileri ise VEC modeli kullanarak analiz etmişlerdir. Ampirik bulgulara göre, kamu iç borçlanmasının büyüme, faiz oranları ve enflasyon üzerinde olumsuz etkiye neden olmaktadır.

Barışık ve Kesikoğlu (2003) ise, 1987:1- 2003:4 verilerini kullanarak bütçe açıklarının makroekonomik değişkenler üzerindeki etkisini test etmek amacıyla Vektör Otoregresyon (VAR) analizi ve Granger nedensellik testi uygulamışlardır. Araştırmada, VAR analizi sonuçlarına göre, bütçe açıkları ile enflasyon, cari açık ve büyüme arasında ilişski tespit edilmiştir. Granger nedensellik testi sonuçlarına göre ise bütçe açıkları ile enflasyon ve cari açık ile büyüme arasında çift yönlü nedensellik ilişkisi tespit edilmiştir.

Çetintaş (2005), 1985:4-2003:4 dönemi için üç aylık verileri kullanarak, bütçe açıkları ile enflasyon ilişkisini önce iki değişkenli, sonra çok değişkenli bir model kullanarak analiz etmiştir. Çalışmada, enflasyonu açıklamada bütçe açıklarının önemli derecede etkin olduğu ve gerek Granger nedensellik sonuçları gerekse Todo-Yamamoto testleri enflasyonla bütçe açığı arasında iki yönlü bir nedenselliğin olduğu sonucuna varmışlardır.

Bütçe açıkları, parasal büyüme ve enflasyon arasındaki uzun dönemli eş bütünleşme ilişkisini analiz etmek amacıyla ARDL sınır testi yaklaşımını kullanan Altıntaş ve diğerleri (2008), değişkenler arasındaki kısa dönemli ilişkiyi test etmek için ise Hata Düzeltme Modeli (VEC) tahmin etmişlerdir. 1992:1- 2006:12 aylık verilerinin kullanıldığı çalışmada elde edilen ampirik sonuçlara göre, enflasyon ile parasal büyüme arasında pozitif ve anlamlı bir ilişki bulunmuştur. Bütçe açıkları ve enflasyon arasında ise, hem uzun hem de kısa dönemde herhangi bir ilişki tespit edilememiştir.

Tanzi ve Patkin etkileri çerçevesinde bütçe açığı ve enflasyon arasındaki ilişkiyi analiz etmek amaciyla Pesaran, Shin ve Smith'in sinır testi analizini kullanan Abdioğlu ve Terzi (2009), 1975-2005 yıllık verilerinin kullanarak, bütçe açıkları ile enflasyon arasında uzun dönemde negatif yönlü bir ilişki olduğunu tespit 
etmişlerdir. Çalışma sonuçlarına göre, enflasyondan kaynaklı reel harcamalarda meydana gelen azalmadan dolayı bütçe açıklarında da bir düşüş meydana geleceğini belirten Patkin etkisinin Türkiye için geçerli olduğu belirtilmiştir.

Erkam ve Çetinkaya (2014) bütçe açıkları ve enflasyon arasındaki nedensellik ilişsisini analiz etmek amacıyla Granger nedensellik testini kullanmışlardır. Çalışma kapsamında 1987:1- 2003:6 dönemi yüksek enflasyon oranlarının olduğu dönem, 2005:1- 2013:6 dönemi ise görece düşük enflasyon oranlarının olduğu dönem olarak ayrı ayrı analiz edilmiştir. Araştırma sonuçlarına göre, yüksek enflasyon dönemlerinde bütçe açıklarından enflasyona nedensellik ilişkisi bulunurken düşük enflasyon dönemlerinde nedensellik ilişkisi bulunmamıştır. Bütçe açıkları ile enflasyon oranı arasındaki eş bütünleşme ilişkisini analiz etmek amacıyla ARDL sınır testini, değişkenler arasındaki nedensellik ilişkisini tespit etmek amaciyla da Toda-Yamamoto nedensellik testini kullanan İpek ve Akar (2016), 2004:1- 2015:2 aylık verilerinin kullandıkları çalışmalarında, değişkenler arasında eş bütünleşme ilişkisi ve çift yönlü nedensellik ilişkisi tespit etmişlerdir.

Çetin (2005), kamu borçlarının iç borç faiz haddi, fiyatlar ve üretim üzerindeki etkisini analiz etmek amacıyla VAR modelinden elde edilen varyans ayrıştırması ve etki tepti fonksiyonunu 1989:01-2004:03 aylık verilerinin kullanarak test etmişlerdir. Elde edilen bulgulara göre, kamu borçlarındaki artış faiz haddi ve fiyatlarda düşüşe neden olmaktadır.

Çoban ve diğerleri (2008) ise kamu iç borçlarının büyüme, enflasyon ve faiz oranları üzerindeki etkisini analiz etmek için Johansen eş-bütünleşme testi ve Granger nedensellik testlerinden yararlanmıştır. 1987-2007 yıllık verilerinin kullanıldığı çalışmada, iç borçlanma ile büyüme arasında eş-bütünleşme ilişkisi tespit edilirken iç borçlanma ve enflasyon arasında eş-bütünleşme ilişkisi bulunamamıştır. Granger nedensellik testi sonuçlarına göre ise iç borçlanma ile büyüme arasında nedensellik ilişkisi olduğu yönünde bulgulara rastlanılmıştır. 1998:01- 2012:01 aylık verilerini kullanarak, kamu iç borçlarının enflasyon ile olan etkileşimini Granger nedensellik testiyle araştıran Ulusoy ve Erdem (2014), kamu iç borçları ve enflasyon arasında çift yönlü nedensellik ilişkisi tespit etmişlerdir. Sonuçlar, iç borçlanmanın enflasyonist etkiler ortaya çıkaracağını ve karşılıklı etkileşim olacağını destekleyen görüşlerle örtüşmektedir. Çoban'nın (2015) 2006-2014 aylık verilerinden yararlanarak, mali disiplin ile enflasyon hedeflemesi arasındaki ilişkiyi analiz etmek amacıyla Granger nedensellik testini kullandığı çalışmada ise mali disiplin göstergesi olarak faiz dışı bütçe dengesi alınmıştır. Granger nedensellik testi sonuçlarına göre, mali disiplin ile enflasyon hedeflemesi arasında çift yönlü nedensellik ilişkisi tespit edilmiştir. Sonuçlara göre, enflasyon hedeflemesinin gerçekleşmesinde mali disiplin politikalarının etkisi bulunmaktadır. Mali disiplinde ortaya çıkabilecek bir gevşeklik ise enflasyon hedeflemesinin başarısını olumsuz etkileyebilecektir.

Tüleykan (2016) faiz dışı bütçe dengesi ile kamu borç stoku, büyüme, faiz oranı ve enflasyon arasındaki ilişkiyi Granger nedensellik testi kullanarak incelemiştir. 
2006-2014 dönemi verilerinin kullanıldığı çalışmada, büyüme oranından faiz dışı bütçe dengesine doğru nedensellik ilişkisi tespit edilmiştir. Çalışma kapsamında yapılan varyans ayrıştırma sonuçlarına göre ise büyüme ve enflasyondaki değişimi açıklamakta faiz dışı bütçe dengesinin pozitif sonuçlar verdiği bulgularına ulaşılmıştır.

Sonuç olarak, literatürde, mali disiplin göstergeleri ile enflasyon arasındaki ilişki konusunda tam bir görüss sağlanamamıştır. Mali disiplinin enflasyonu artırdığına, azalttığına ve iki değişken arasında karşılıklı ilişki olduğuna yönelik çalışmalar bulunmaktadır. Diğer yandan, çalışma kapsamında seçilen göstergelerin enflasyon ile nedensellik ilişkisi farklı çalışmalarda genellikle Granger nedensellik testi ile analiz edilmiştir. Araştırma kapsamında ise Toda-Yamamoto (1995) nedensellik testi ile değişkenler arasındaki nedensellik ilişkisinin tespit edilmesi amaçlanmıştır.

\section{Veri Seti, Ekonometrik Yöntem ve Bulgular}

$\mathrm{Bu}$ çalışmada, mali disiplin göstergeleri olarak belirlenen bütçe dengesi, faiz dış1 bütçe dengesi ve kamu borç stokunun enflasyon ile olan etkileşimi zaman serileri yardımıyla test edilmiştir. Çalışma kapsamında 1980-2016 dönemi yıllık verileri kullanılmıştır. Çalışmada, 1980-2016 döneminin alınmasının amacı; Türkiye'de mali dengelerdeki bozulmanın 1980'li yıllarda başlaması ve 1980 istikrar kararlarında bütçe açığını GSYH yüzde 2'sine çekme ve borç seviyesinin azaltılmasına yapılan vurgunun (Şahin, 2011: 191) yanında, özellikle 1990'l1 yıllarda bütçe açığı ve borç seviyesindeki yükselme kaynaklı krizler ve son olarak da 2001 krizinden günümüze kadar uygulanan istikrar programlarında mali disiplinin sağlanmasının enflasyonun kontrol edilmesinin temel aracı olarak alınmış olmasıdır. Ekonometrik analizde kullanılan değişkenler ise Tablo 1'de verilmiştir.

Tablo 1: Veri Seti Tanitımı

\begin{tabular}{|l|l|l|}
\hline Değişken & \multicolumn{1}{|c|}{ Veri Tanım } & \multicolumn{1}{|c|}{ Kaynak } \\
\hline EO & $\begin{array}{l}\text { TÜFE endeksinde y1llık artış1 } \\
\text { gösteren enflasyon oranı olarak } \\
\text { analize dahil edilmiştir. }\end{array}$ & Kalkınma Bakanlığ1 \\
\hline BD & $\begin{array}{l}\text { Bütçe dengesinin GSYH içindeki } \\
\text { pay1. }\end{array}$ & $\begin{array}{l}\text { Bütçe ve Mali Kontrol Genel } \\
\text { Müdürlüğü }\end{array}$ \\
\hline FDD & $\begin{array}{l}\text { Faiz dı̧1 bütçe dengesinin GSYH } \\
\text { içindeki payı. }\end{array}$ & $\begin{array}{l}\text { Bütçe ve Mali Kontrol Genel } \\
\text { Müdürlüğü }\end{array}$ \\
\hline BS & $\begin{array}{l}\text { Kamu borç stokunun GSYH içindeki } \\
\text { payı. }\end{array}$ & Hazine Müsteşarlığ1 \\
\hline
\end{tabular}

Grafik 1'de çalışma kapsamında ele alınan serilerin yıllar itibari ile seyri ele alınmıştır. Birincil eksen enflasyon oranı ve kamu borç stoku verilerini gösterirken, ikincil eksen bütçe dengesi ve faiz dışı bütçe dengesi verilerini göstermektedir. 
Grafik 1: Türkiye'de Bütçe Dengesi, Faiz Dışı Bütçe Dengesi ve Kamu Borç Stokunun GSYH İçindeki Payı ve Enflasyon Oranı

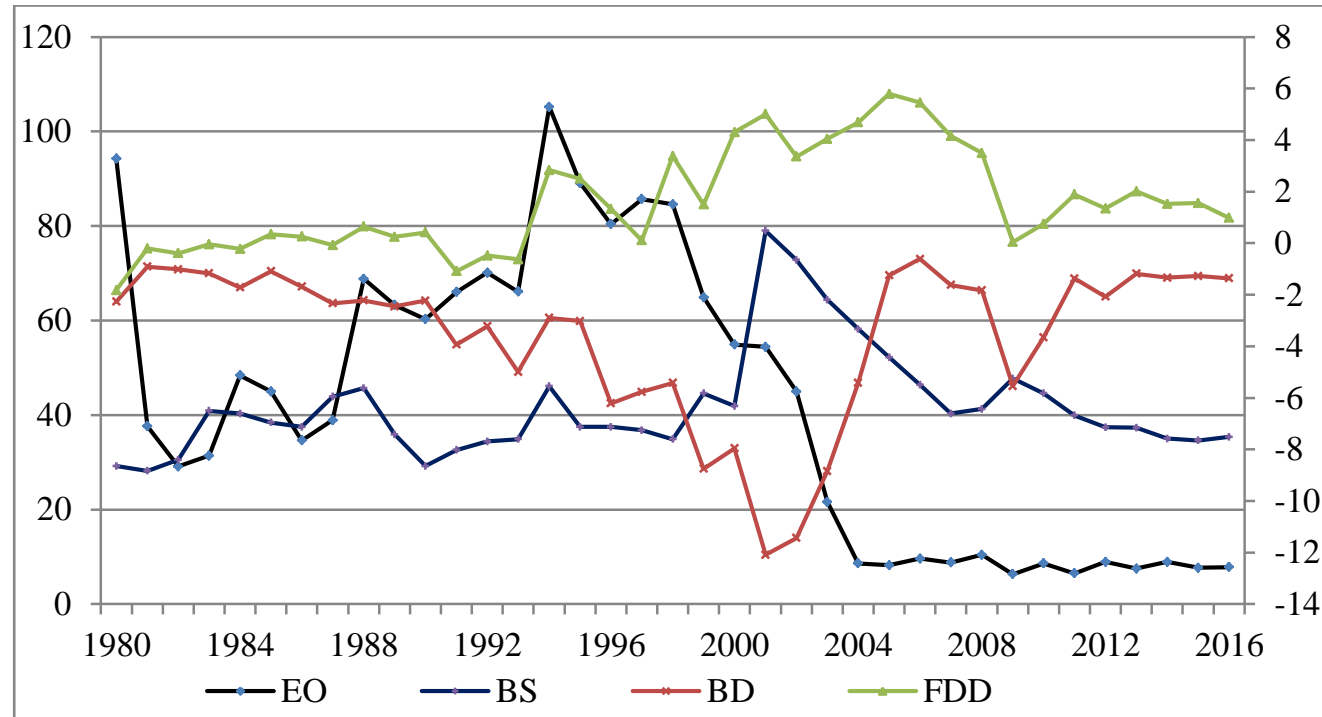

Kaynak: Tablo 1'de belirtilen veri tabanlarından yararlanılarak tarafimızdan çizilmiştir.

Grafik 1'de görüleceği üzere 1990 yılına kadar faiz dışı bütçe dengesi sıfır seviyesinde seyrederken, bütçe açıkları artma eğilimi göstermiştir. Bu durum daha çok borçlanmaya başvurulmasından ve borçlanmanın maliyeti olan faiz giderlerinin artış göstermesinden kaynaklanmaktadır. Program hedefleri çerçevesinde enflasyon oranı yüzde 94,3'ten yüzde 31,4'e kadar düşürülmüş ancak takip eden yıllarda enflasyon oranı artış göstermeye başlamıştır. 1989 yılından sonra bütçe açıkları artmaya devam etmiş, bütçe açıklarının iç borçlanma ile finansmanı faiz oranları artmış ve beraberinde bütçe açıkları artmaya devam etmiştir. Diğer yandan, enflasyon oranı üç haneli rakamlara çıkmıştır. Bu kısır döngü 5 Nisan 1994 kararları alınana denk devam etmiştir. 1994 yılında ilk olarak yüzde 3 düzeylerinde faiz dışı bütçe fazlası sağlanmıştır. Bütçe açığı 1995 yılında azalmış ancak mali disiplin programı başarılı bir şekilde sürdürülemediği için tekrar artış göstermiştir. 1994 yılından sonra kamu borç stoku da artış göstermiştir. Her ne kadar kamu dış borç stokunda azalma olsa da kamu iç borç stokundaki artıştan dolayı toplam kamu borç stoku artmıştır. Enflasyon oranında ise 2000 y1lına bir düşüş sağlansa da ancak istenilen düzeye düşürülememiştir (Ulusoy, 2014: 124-126; Grafik 1).

2001 yılında Güçlü Ekonomiye Geçiş Programı (GEGP) imzalanmıştır. Program kapsamında öncelikle artan kamu borç stoku ve bütçe açıklarına çözüm üretmek amaçlanmıştır. Bu nedenle mali disiplini sağlamak için faiz dışı bütçe fazlasının GSYH içindeki payını yüzde 6,5'e çıkarmak maliye politikası hedefi olarak belirlenmiştir (Susam, 2009: 218). Program başarılı bir şekilde uygulanarak; hedeflenen faiz dışı bütçe fazlası sağlanmış, bütçe açıkları azalmaya başlamış, kamu borç stokunun GSYH içindeki payı da azalmıştır. GEGP çerçevesinde 2002 
yılında gelecek yıl enflasyon beklentilerini yönetmek amacıyla örtük enflasyon hedeflemesi uygulanmıştır. $\mathrm{Bu}$ yöntemin başarılı olması neticesinde enflasyon oranı tek haneli rakamlara ulaşmıştır (Oğuz, 2010: 13-16).

Türkiye'de mali dengelerdeki olumlu gelişmeler 2008 küresel krizden sonra bozulmaya başlamıştır. Nitekim bütçe açıklarının payı yüzde 5,5'e kadar çıkarken, faiz dışı bütçe fazla oranı yüzde sıfıra kadar düşmüştür. Kriz sonrasında, ekonomide hızlı toparlanma sürecinin başlaması ve mali disiplinden taviz verilmemesinin etkisiyle bütçe açıkları azalma eğilimine devam etmiş, faiz dışı bütçe fazlası yüzde 2 seviyelerinde tutulmuştur. Kamu borç stoku oranı krizle birlikte bir artış göstermiş ancak süre gelen yıllarda azalmaya devam etmiştir. $\mathrm{Bu}$ yıllarda fiyat istikrarının sağlanmasına verilen önem devam etmiştir (Grafik 1).

Araştırma kapsamında Türkiye'de 1980-2016 yılları arasında uygulanan mali disiplin politikalarının enflasyon ile olan etkileşimini araştırmak amaçlanmıştır. Dönemin uzunluğu ve dönem içinde birçok ekonomik olayın yaşanması (5 Nisan 1994 kararları, 2001 Krizi, 2008 Küresel Finansal Kriz) nedeniyle, serilerin durağanlık dereceleri yapısal kırılmayı dikkate alan Zivot ve Andrews (1992) birim kök testi ve LM birim kök testi (Lee ve Strazicich, 2004, 2013) ile analiz edilmiştir. Bütçe dengesi/GSYH oranı, kamu borç stoku/GSYH oranı ve faiz dışı bütçe dengesi/GSYH oranının enflasyon oranı ile etkileşimi analiz etmek amaciyla Toda ve Yamamoto (1995) nedensellik testinden yararlanılmıştır. Ayrıca, etki-tepki fonksiyonları aracılığıyla serilerin davranışlarında meydana gelen bir şokun etkilerinin zaman profili ölçülmeye çalışılmıştır.

Serilerin birim kök özellikleri yapısal kırılmayı dikkate alan Zivot-Andrews (ZA) birim kök testi ve tek kırılmalı Langrange Çarpanları (LM) birim kök testi ile tespit edilmiştir. Perron (1989) testinde kırılmanın dişsal olarak bilindiği varsayımını yapmaktadır. Yapısal kırılma dışsal olarak alındığında serilerin durağan olduğuna dair bir sonuçla karşılaş1labilir. Bu nedenle, Zivot ve Andrews (1992), Perron (1989) testini eleştirerek kırılmanın içsel olarak belirlendiği ZA birim kök testini geliştirmişlerdir. Zivot ve Andrews (1992) birim kök testi aşağıdaki modellerle açıklanmaktadır:

$$
\begin{aligned}
& y_{t}=\mu+\theta D U_{t}(\lambda)+\beta t+\alpha y_{t-1}+\sum_{j=1}^{k} c_{j} \Delta y_{t-j}+e_{t} \\
& y_{t}=\mu+\gamma D T_{t}(\lambda)+\beta t+\alpha y_{t-1}+\sum_{j=1}^{k} c_{j} \Delta y_{t-j}+e_{t} \\
& y_{t}=\mu+\theta D U_{t}(\lambda)+\beta t+\gamma D T_{t}(\lambda)+\alpha y_{t-1}+\sum_{j=1}^{k} c_{j} \Delta y_{t-j}+e_{t}
\end{aligned}
$$

Model 1 sabitteki kırılmayı, Model 2 trenddeki kırılmayı, Model 3 hem sabit hem de trenddeki kırılmayı temsil etmektedir. $\mathrm{T}=1,2,3 \ldots \mathrm{T}$ zamanı, $\mathrm{T} \lambda=\mathrm{T}_{\mathrm{B}}$ dolayısıyla $\lambda=\mathrm{T}_{\mathrm{B}} / \mathrm{T}$ kırılma noktasını, $\mathrm{T}_{\mathrm{B}}$ modelde belirlenen kırılma zamanını belirtir. $\mathrm{DU}_{\mathrm{t}}(\lambda)$ eğer $\mathrm{t}>\mathrm{T} \lambda$ ise 1 , diğer durumlarda sıfır değerini alan ve sabit terimde meydana gelen yapısal kırılmayı gösteren kukla değişkendir. DT( $\lambda)$ için; eğer $\mathrm{t}>\mathrm{T} \lambda$ ise $\mathrm{t}-$ $\mathrm{T} \lambda$, değilse sıfır değerini alan ve trenddeki yapısal kırılmayı gösteren kukla değişkenlerdir. 
ZA birim kök testinde $\alpha$ değerinin t istatistikleri ZA tablo kritik değerleri ile karşılaştırılır. $t$ istatistiği ZA tablo kritik değerinden mutlak değer olarak büyük ise birim kökün varlığını gösteren sıfır hipotezi reddedilir. Sıfır hipotezinin reddedilmesi serinin yapısal kırılma nedeniyle durağan olduğunu ifade etmektedir.

Tablo 2'de, ZA birim kök testinde Model 1 ve Model 3 dikkate alınmıştır. Genel olarak iktisadi seriler bu modellerle modellenebileceği için Model 2 çalışma kapsamı dışında tutulmuştur. EO, BD, FDD ve BS serilerinin Model $1 \mathrm{t}$ istatistikleri seviye değerlerinde mutlak değer içinde ZA tablo kritik değerinden küçük olduğu için farkları alınmıştır. Model 1'e göre birinci farklarında \%1 anlamlılık düzeyinde yapısal kırılmalı durağan tespit edilmişlerdir. Model 3'de ise EO ve FDD serileri seviye değerlerinde sıfir hipotezi reddedilemez iken, BD \%5 anlamlılık düzeyinde, BS ise \%1 anlamlılık düzeyinde yapısal kırılmalı durağan tespit edilmiştir.

Tablo 2: Zivot- Andrews Birim Kök Testi Sonuçları

\begin{tabular}{|l|c|c|c|c|c|c|c|c|}
\hline \multirow{2}{*}{ Değişkenler } & \multicolumn{4}{|c|}{ Model 1 } & \multicolumn{4}{c|}{ Model 3 } \\
\cline { 2 - 9 } & \multicolumn{2}{|c|}{$\mathrm{I}(0)$} & \multicolumn{2}{|c|}{$\mathrm{I}(1)$} & \multicolumn{2}{c|}{$\mathrm{I}(0)$} & \multicolumn{2}{c|}{$\mathrm{I}(1)$} \\
\cline { 2 - 9 } & $\mathrm{T}$ & $\mathrm{T}_{\mathrm{B}}$ & $\mathrm{T}$ & $\mathrm{T}_{\mathrm{B}}$ & $\mathrm{T}$ & $\mathrm{T}_{\mathrm{B}}$ & $\mathrm{T}$ & $\mathrm{T}_{\mathrm{B}}$ \\
\hline EO & $-2,632$ & 2000 & $-5,614^{\mathrm{a}}$ & 2003 & $-1,466$ & 2013 & $-5,579^{\mathrm{a}}$ & 2013 \\
\hline BD & $-4,207$ & 2008 & $-6,112^{\mathrm{a}}$ & 2001 & $-5,365^{\mathrm{b}}$ & 1997 & --- & --- \\
\hline FDD & $-3,736$ & 2007 & $-7,878^{\mathrm{a}}$ & 2004 & $-4,455$ & 1997 & $-8,222^{\mathrm{a}}$ & 2005 \\
\hline BS & $-3,508$ & 1997 & $-6,268^{\mathrm{a}}$ & 1996 & $-9,311^{\mathrm{a}}$ & 1999 & --- & --- \\
\hline
\end{tabular}

Not: Tablo Kritik Değerleri Model 1 için \%1; -5,34, \%5; -4,80, \%10; -4,58, Model 3 için \%1; -5,57, \%5; $5,08, \% 10 ;-4,82$ 'dir. a ve $\mathrm{b}$ sirasıyla serilerin $\% 1$ ve $\% 5$ anlamlılık düzeyinde durağan olduklarını göstermektedir.

ZA birim kök testi birim kökün varlığını gösteren sıfır hipotezi altında kırılmanın gerçekleşme ihtimalini modele dahil etmemektedir. Bu nedenle kırılmanın varlığ ile durağan olan seriler durağan değilmiş gibi ifade edilecektir. Lee ve Strazicich (2004, 2013) ZA testinde kullanılan sifir hipotezinin alternatifinin yapısal kırılmalı durağan olmaması gerektiğini ortaya koymuşlardır. Lee ve Strazicich $(2004,2013)$ bu sorunu ortadan kaldırabilmek için ADF tipi test stratejisi yerine LM tipi test stratejisine dayanan tek kırılmalı LM birim kök testini geliştirmişlerdir. LM birim kök testi aşağıdaki modelle açıklanmaktadır (Lee ve Strazicich; 2004, 2013):

$\Delta y_{t}=\delta \Delta Z_{t}+\emptyset S_{t-1}+\varepsilon_{t}$

$S_{t-1}=y_{t}-\psi_{x}-Z_{t} \delta, \quad \mathrm{t}=2, \ldots, \quad \mathrm{T}$ şeklindedir. $\psi_{x}, y_{t}-Z_{t} \delta$ 'dan elde edilmektedir. $\delta$ ise $\Delta y_{t}$ 'nin $\Delta Z_{t}$ 'ye regresyonundan elde edilen katsayıları ifade etmektedir. LM test istatistiğinde kırılma zamanlarını belirlemek için $\tau$ test istatistiğinin en düşük olduğu nokta seçilir.

Tablo 3 tek yapısal kırılmanın varlığına izin veren LM birim kök testi sonuçlarını göstermektedir. Model 1 sabitte, Model 3 ise trendde meydana gelen kırılmayı ifade etmektedir. Model 1'e göre EO, BD, FDD ve BS birinci farklarında \%1 
anlamlılık düzeyinde yapısal kırılmalı durağan olarak tespit edilmiştir. Model 3'e göre ise, FDD seviyesinde \%10 anlamlılık düzeyinde yapısal kırılmalı durağan iken, EO, BD ve BS birinci farklarında \%1 anlamlılık düzeyinde yapısal kırılmalı durağan olarak tespit edilmiştir.

Tablo 3: Tek Kırılmalı LM Birim Kök Testi Sonuçları

\begin{tabular}{|c|c|c|c|c|c|c|c|c|}
\hline \multirow{3}{*}{ Değişkenler } & \multicolumn{4}{|c|}{ Model 1} & \multicolumn{4}{|c|}{ Model 3} \\
\hline & \multicolumn{2}{|c|}{$\mathrm{I}(0)$} & \multicolumn{2}{|c|}{$\mathrm{I}(1)$} & \multicolumn{2}{|c|}{$\mathrm{I}(0)$} & \multicolumn{2}{|c|}{$\mathrm{I}(1)$} \\
\hline & $\mathrm{T}$ & $\mathrm{T}_{\mathrm{B}}$ & $\mathrm{T}$ & $\mathrm{T}_{\mathrm{B}}$ & $\mathrm{T}$ & $\mathrm{T}_{\mathrm{B}}$ & $\mathrm{T}$ & $\mathrm{T}_{\mathrm{B}}$ \\
\hline EO & $-1,666$ & 1998 & $-5,926^{\mathrm{a}}$ & 1998 & $-2,536$ & 2001 & $-2,677$ & 1994 \\
\hline $\mathrm{BD}$ & $-2,299$ & 2003 & $-6,770^{\mathrm{a}}$ & 2002 & $-3,524$ & 1995 & $-6,818^{a}$ & 2002 \\
\hline FDD & $-2,817$ & 1993 & $-8,135^{\mathrm{a}}$ & 2004 & $-4,250^{\mathrm{c}}$ & 1999 & --- & --- \\
\hline BS & $-2,597$ & 1998 & $-6,345^{a}$ & 2001 & $-3,235$ & 1998 & $-6,595^{a}$ & 2001 \\
\hline
\end{tabular}

Not: Tablo kritik değerleri Model 1 için \%1; -4,23, \%5; -3,56, \%10; -3,21, Model 3 için \%1; -5,11, \%5; -$4,50, \% 10 ;-4,21$ 'dir. a ve c sirasiyla serilerin $\% 1$ ve $\% 10$ anlamlılık düzeyinde durağan olduklarını göstermektedir.

Zaman serileri analizlerinde kullanılan değişkenlerin durağanlık şartını sağlamaları güvenilir analizler için öncelikli şartlardan birisidir. ZA ve tek kırılmalı LM birim kök testi sonuçlarına göre serilerin birinci farklarında yapısal kırılmalı durağan oldukları belirlenmiştir. Birinci farkında durağan olarak tespit edilen serilerin seviye değerlerinde bilgi kaybı yaşanmaktadır. Toda-Yamamoto (1995) nedensellik testinde seriler seviyesinde test edildiği için bu bilgi kaybı ortadan kalkmaktadır. Çalışma kapsamında tüm değişkenler birinci farkında yapısal kırılmalı durağan olarak tespit edilmiş ve Tado-Yamamoto nedensellik analizi kullanılmıştır.

Toda ve Yamamoto (1995) nedensellik analizinde ilk olarak değişkenlerin maksimum durağanlık derecesi $\left(d_{\max }\right)$ ve optimal gecikme uzunluğunu $(\mathrm{k})$ belirlemektedir. VAR modelinde optimal gecikme uzunluğunun belirlenebilmesi için AIC, SCI ve Hannan-Quin (HQ) gibi bilgi kriterlerinden yararlanılmaktadır. İkinci aşamada ise optimal gecikme uzunluğuna eklenen $d_{\max }$ gecikmelerine karşı gelen katsayılar ihmal edilerek Wald testi uygulanmaktadır.

Toda-Yamamoto nedensellik testi için tahmin edilen modeller aşağıdaki denklemler yardımıyla gösterilmektedir:

$$
\begin{aligned}
& E O_{t}=\gamma_{0}+\sum_{j=1}^{k+d \max } \alpha_{1 j} E O_{t-j}+\sum_{j=1}^{k+d \max } \beta_{1 j} B D_{t-j}+\varepsilon_{1 t} \\
& B D_{t}=\beta_{0}+\sum_{j=1}^{k+d \operatorname{dmax}} \theta_{1 j} E O_{t-j}+\sum_{j=1}^{k+d \max } \mu_{1 j} B D_{t-j}+\varepsilon_{2 t} \\
& E O_{t}=\gamma_{0}+\sum_{j=1}^{k+d \max } \alpha_{1 j} E O_{t-j}+\sum_{j=1}^{k+d \max } \beta_{1 j} F D D_{t-j}+\varepsilon_{1 t} \\
& F D D_{t}=\beta_{0}+\sum_{j=1}^{k+d \max } \theta_{1 j} E O_{t-j}+\sum_{j=1}^{k+d \max } \mu_{1 j} F D D_{t-j}+\varepsilon_{2 t} \\
& E O_{t}=\gamma_{0}+\sum_{j=1}^{+d \operatorname{dmax}} \alpha_{1 j} E O_{t-j}+\sum_{j=1}^{k+d \max } \beta_{1 j} B S_{t-j}+\varepsilon_{1 t} \\
& B S_{t}=\beta_{0}+\sum_{j=1}^{k+d \max } \theta_{1 j} E O_{t-j}+\sum_{j=1}^{k+d \max } \mu_{1 j} B S_{t-j}+\varepsilon_{2 t}
\end{aligned}
$$


Çalışma kapsamında 6 model tahmin edilmiştir. Araştırma kapsamında öncelikle kurulan modellerin uygun gecikme uzunlukları belirlenmiştir. Gecikme uzunluklarının belirlenmesinde AIC bilgi kriteri dikkate alınmıştır. Uygun gecikme uzunluğu Model 5 için $\mathrm{k}=3$, Model 7 için $\mathrm{k}=2$ ve Model 9 için $\mathrm{k}=3$ olarak belirlenmiştir. Makroekonomik verilerin kullanıldığı çalışmalarda $d_{\max }=$ 1 olarak kullanılması dikkate alınarak bu çalışma kapsamında da kullanılmıştır.

Tablo 4: Toda-Yamamoto Nedensellik Testi Sonuçları

\begin{tabular}{|l|c|c|c|c|}
\hline \multicolumn{1}{|c|}{ Model } & $\begin{array}{c}\text { Gecikme } \\
\text { Uzunluğu }\end{array}$ & Wald Test & $\begin{array}{c}\text { Katsayılar } \\
\text { Toplamı }\end{array}$ & Nedensellik \\
\hline $\mathrm{EO}=f(\mathrm{BD})$ & $k=3$ & $14,330(0,003)$ & $2,656(0,009)$ & $\mathrm{BD} \rightarrow \mathrm{EO}$ \\
$\mathrm{BD}=f(\mathrm{EO})$ & $d_{\max }=1$ & $2,330(0,507)$ & $-0,013(0,484)$ & Yok \\
\hline $\mathrm{EO}=f(\mathrm{FDD})$ & $k=2$ & $5,247(0,072)$ & $-2,526(0,091)$ & FDD $\rightarrow \mathrm{EO}$ \\
$\mathrm{FDD}=f(\mathrm{EO})$ & $d_{\max }=1$ & $0,962(0,617)$ & $-0,011(0,438)$ & Yok \\
\hline $\mathrm{EO}=f(\mathrm{BS})$ & $k=3$ & $11,807(0,008)$ & $-0,659(0,009)$ & $\mathrm{BS} \rightarrow \mathrm{EO}$ \\
$\mathrm{BS}=\mathrm{f}(\mathrm{EO})$ & $d_{\max }=1$ & $16,777(0,000)$ & $0,008(0,914)$ & $\mathrm{EO} \rightarrow \mathrm{BS}$ \\
\hline
\end{tabular}

Not: Ok işaretleri nedenselliğin yönünü göstermektedir.

Tablo 4'deki bulgulara göre bütçe dengesinden enflasyon oranına pozitif yönlü, faiz dışı bütçe dengesinde enflasyon oranına negatif yönlü nedensellik ilişkisi bulunmaktadır. Ayrıca kamu borç stoku ve enflasyon oranı arasında çift yönlü nedensellik ilişkisi tespit edilmiştir. Kamu borç stokundan enflasyon oranına negatif yönlü anlamlı bir nedensellik ilişkisi bulunurken, enflasyon oranından kamu borç stokuna tespit edilen nedensellik ilişkisinin yönü anlamlı değildir.

Tahmin edilen modellerin diagnostik testleri Tablo 5'de verilmiştir. Sonuçlar, tahmin edilen modellerde diagnostik sorunların olmadığını göstermektedir.

Tablo 5: Diagnostik Testler

\begin{tabular}{|l|c|c|c|}
\hline \multicolumn{1}{|c|}{ Model } & $\begin{array}{c}\text { AR Kökler } \\
\text { max;min }\end{array}$ & LM İstatistiği & White $\boldsymbol{x}^{\mathbf{2}}$ \\
\hline Model 5 & 0,$900 ; 0,326$ & $0,944(0,918)$ & $28,699(0,988)$ \\
\hline Model 7 & 0,$930 ; 0,123$ & $5,672(0,225)$ & $39,163(0,392)$ \\
\hline Model 9 & 0,$888 ; 0,447$ & $3,400(0,493)$ & $38,503(0,834)$ \\
\hline
\end{tabular}

Etki-tepki fonksiyonları VAR modeli yardımı ile elde edilmektedir. Etki-tepki fonksiyonu, hata terimlerinin birindeki bir standart sapmalık şoka karşı içsel değişkenin tepkisini ölçer. Bu fonksiyon için gerekli olan güven aralığı Monte Carlo similasyonları yardımı ile türetilmiştir ( grafiklerde yer alan kesikli çizgiler $\mp 2$ standart hata için elde edilen güven aralıklarını gösterirken, düz çizgiler hata terimlerinde meydana gelen 1 standart sapmalık şoka karşı bağımlı değişkenin zaman içinde gösterdiği tepkiyi belirtmektedir. Sonuçların anlamlı kabul edilebilmesi için güven araklılarının sıfır seviyesinin üstünde ya da altında olması gerekmektedir (Yamak ve Korkmaz, 2005: 23-26). 
Şekil 1: Etki-Tepki Fonksiyonları

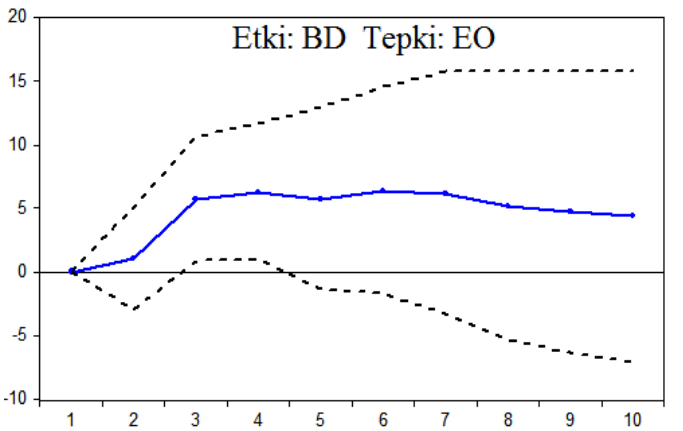

Grafik (a)

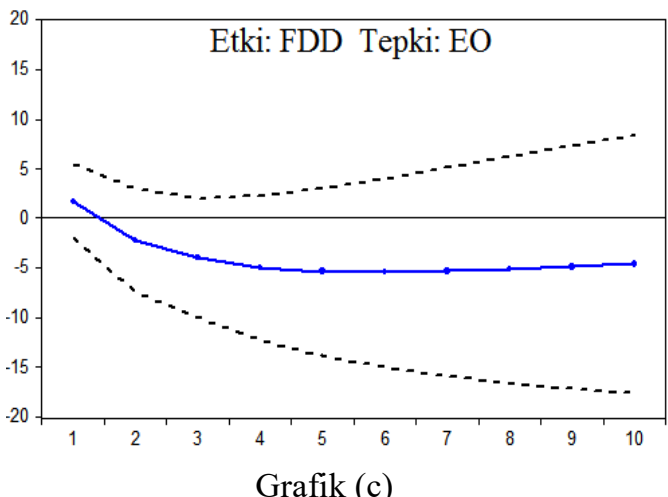

Grafik (c)

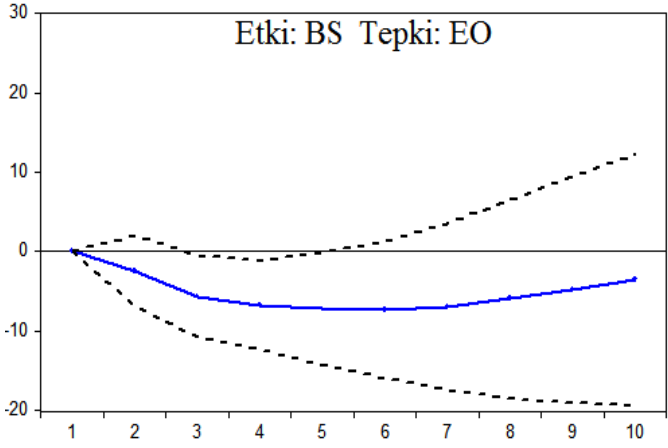

Grafik (e)

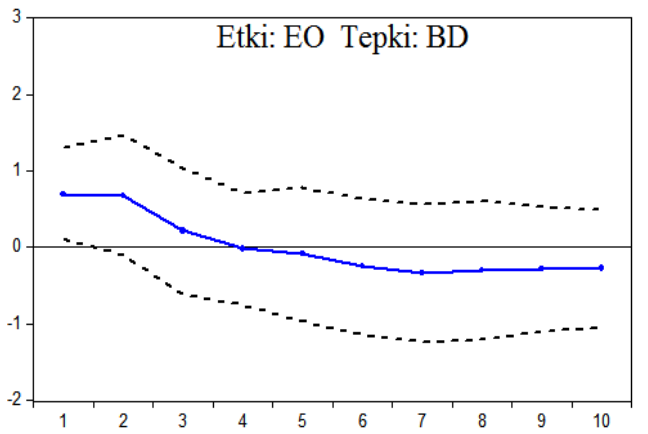

Grafik (b)

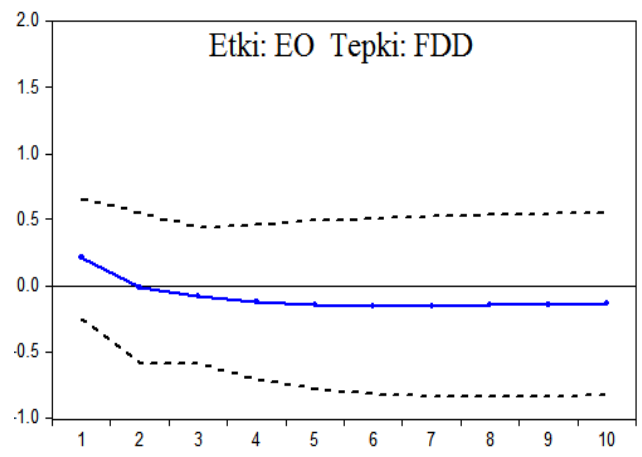

Grafik (d)

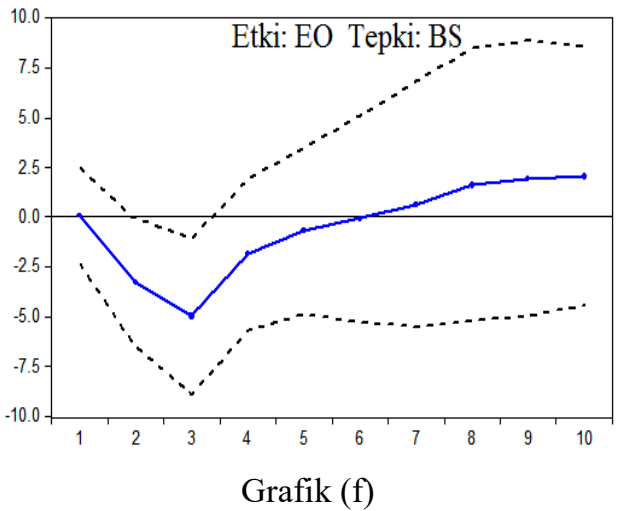

VAR modelinden elde edilen etki-tepki analiz sonuçları Şekil 1'de gösterilmektedir. Şekil 1'de verilen grafik (a)'da ilk olarak bütçe dengesindeki bir standart hatalık şokun enflasyon oranı üzerindeki etkisi görülmektedir. Grafikte görüldügü üzere etki başlangıçta pozitif ancak zayıfken, ikinci dönemde etki şiddetlenmiş, üçüncü ve dördüncü dönemde pozitif yönde devam ederek sonrasında zayıf bir seyir izlemiştir. Grafik (b), enflasyon oranındaki bir standart hatalık şokun bütçe dengesi üzerindeki etkisini göstermektedir. Birinci ve ikinci dönemde etki pozitifken, sonrasında negatife dönmekte ve giderek zayıflayan bir seyir izlemektedir. Grafik (c)'de ise faiz dışı bütçe dengesindeki bir standart 
hatalık şokun enflasyon oranı üzerindeki etkisi görülmektedir. Söz konusu etkiler negatif olarak gözlemlenmekle beraber istatistiksel olarak anlamsızdır.

Grafik (d)'de enflasyon oranı değişkenine ait seriye uygulanan bir şokun faiz dışı bütçe dengesi üzerindeki etkisi verilmiştir. Etki negatif bir görünümde olmakla birlikte istatistiksel olarak anlamsızdır. Grafik (e)'de ise kamu borç stokundaki bir standart hatalık şokun enflasyon oranı üzerindeki etkisi gösterilmektedir. Etki başlangıçta negatiftir ve ikinci dönemden sonra etkisi artarak devam etmektedir. Altıncı ve yedinci dönemin ardından etki giderek zayıflamakta ve pozitife dönüşmektedir. Son olarak grafik (f)'de bir standart hatalık bir enflasyon oranı şokunun kamu borç stoku üzerindeki etkisi gösterilmektedir. Etki negatif bir görünümle başlamakta ve üçüncü dönemin sonuna kadar şiddetli bir görünüm arz etmekte ve altıncı dönemden sonra pozitife dönerek gittikçe zayıflayan bir seyir izlemektedir.

\section{Sonuç}

Mali disiplin (veya mali disiplin unsurları) ile enflasyon arasındaki ilişki ekonomi literatüründe üzerinde düşünülen ve analizler yapılan bir konudur. Türkiye özelinde, özellikle 1990'lı yıllarda yüksek bütçe açığına (mali disiplinin olmayışı) eşlik eden yüksek (çift haneli hatta bazı yıllar üç haneli) enflasyon 1994, 1998 ve 2000 ve 2001 krizinin nedenleri arasında görülmektedir. Enflasyonun en önemli istikrarsızlık olarak ele alınıp istikrar programlarıyla kontrol altına alınmaya çalışıldığı 2001 krizinden itibaren ise mali disiplin bu çerçevede faiz dışı fazla verilmesi istikrar programlarının ve enflasyonu kontrol altına almanın en önemli unsuru olarak değerlendirilmiştir.

Türkiye açısından, mali göstergelerde bozulmanın kendini gösterdiği 1980'li yıllardan itibaren güçlü olmasa da mali disiplin arayışı söz konusudur. Türkiye ekonomisini ele alan bu çalışmada, mali disiplin unsurları olarak görülen bütçe dengesi, faiz dişı bütçe dengesi ve kamu borç stokunun enflasyon üzerindeki etkisinin ampirik olarak incelenmesi amaçlanmıştır. Bu amaçla gerçekleştirilen analizlerde Türkiye ekonomisinin 1980-2016 dönemi yıllık verileri kullanılarak Toda-Yamamoto nedensellik testi ve etki-tepki fonksiyon analizi yapılmıştır.

Toda-Yamamoto nedensellik testi sonuçlarına göre, bütçe dengesinden enflasyon oranına tek yönlü pozitif nedensellik ilişkisi tespit edilmiştir. Değişkenler arasındaki ilişkinin anlamlılık düzeyinin \%1 olması, bütçe açıklarının enflasyon oranını artırmada önemli bir etken olduğunu göstermektedir, ilave olarak da, sonuçlara göre, bütçe açıklarındaki artış enflasyon oranında bir artışa neden olmaktadır. Etki-tepki fonksiyonları analizi de Toda-Yamamoto nedensellik sonuçları ile uyuşmaktadır. Diğer yandan, faiz dışı bütçe dengesinden enflasyon oranına tek yönlü negatif nedensellik ilişkisi tespit edilmiştir. \%10 anlamlılık düzeyinde elde edilen bulgular, faiz dışı bütçe fazlasının enflasyon oranı üzerinde azaltıcı yönde etkisinin olduğunu göstermekte ve literatür ile uyumludur. $\mathrm{Bu}$ bağlamda, mali disiplin sağlamaya yönelik önemli bir politika aracı olan faiz dışı 
bütçe dengesinin enflasyon oranı ile bu yöndeki ilişkisinin tespit edilmesi, para ve maliye politikası koordinasyonu ile enflasyon hedeflemesinin gerçekleştirilmesinde önemli katkılar sağlayacaktır. Ele alınan periyotta mali disiplin (özellikle de bütçe dengesi ve faiz dışı denge) ile enflasyon arasında pozitif bir ilişkin varlığ 1 tespit edilmiştir. Bütçe dengesi ve faiz dışı dengede bir iyileşme, yani mali disiplinde sağlanan bir başarı, enflasyonu kontrol altına almak açısından önemlidir.

İlave olarak, kamu borç stokları ile enflasyon oranı arasında çift yönlü nedensellik ilişkisi tespit edilmiştir. Kamu borç stokundan enflasyon oranına negatif yönlü ilişki tespit edilirken, enflasyon oranından kamu borç stokuna tespit edilen ilişsinin yönü anlamlı sonuç vermemektedir. Etki-tepki fonksiyonları analizi de bu bulgularla eşleşmektedir. Etki-tepki analizi sonuçlarına göre, bütçe açıklarına verilen bir birimlik standart şoka enflasyon oranı üçüncü ve dördüncü dönemlerde pozitif yönde tepki vermektedir. Faiz dışı bütçe fazlasına uygulanan bir birimlik şok karşısında enflasyon oranının tepkisi negatif olmakla birlikte, sonuçlar istatistiki olarak anlamlı değildir. Diğer yandan enflasyon oranı değişkeni, kamu borç stoku değişkeninde meydana gelen bir birimlik standart şoka üçüncü ve dördüncü dönemlerde istatistiki olarak anlamlı ve negatif yönlü tepki vermektedir. Enflasyon oranına verilen bir standart sapmalık şok ise, kamu borç stokunu yaklaşık olarak iki dönem negatif yönlü etkilemektedir. Ancak ilerleyen süreçte kamu borç stokunun tepkisi değişerek pozitif yönlü olmaktadır.

Sonuç olarak, çalışmanın bulguları, Türkiye'de mali gevşemenin (bütçe açığında artışın) enflasyonu artırıcı yönde etkisi olduğunu desteklemektedir. Özellikle 2001 krizinden sonra mali disiplinin en önemli unsuru olarak alınan faiz dışı bütçe fazlasının enflasyon oranı ile negatif yönde ilişkisinin tespit edilmiş olması, faiz dışı bütçe fazlasının enflasyonla mücadele programlarında önemli bir araç olduğunu göstermektedir. Kamu borç seviyesinin enflasyon üzerindeki negatif yönlü etkisi tespit edilen literatürden farklı bir sonuç olmaktadır. $\mathrm{Bu}$ farklılaşmanın nedeni ise, fiyatlar genel seviyesinin borç seviyesindeki değişime gecikmeli tepki vermesi ve ampirik kanitlara dayanmamakla birlikte Ricardian denklik hipotezinin Türkiye açısından kısmende olsa geçerli olduğu şeklinde yorumlanabilir.

\section{Kaynakça}

Abdioğlu, Z. ve Terzi, H. (2009), "Enflasyon ve Bütçe Açıkları İlişkisi: Tanzi ve Patinkin Etkisi”, Atatürk Üniversitesi Iktisadi ve İdari Bilimler Fakültesi Dergisi, 23(2), 195-211.

Altıntaş, H., Çetintaş, H. ve Taban, S. (2008), “Türkiye'de Bütçe Açı̆̆ı, Parasal Büyüme ve Enflasyon Arasındaki İlişkinin Ekonometrik Analizi: 1992-2006”, Anadolu Üniversitesi Sosyal Bilimler Dergisi, 8(2), 185-208. 
Barişik, S. ve Kesikoğlu, F. (2006), "Türkiye'de Bütçe Açıklarının Temel Makro Ekonomik Değişkenler Üzerine Etkisi (1987-2003 VAR, Etki-Tepki Analizi, Varyans Ayrıştırması", Ankara Üniversitesi SBF Dergisi, 61(4), 59-82.

Barrios, S., Langedijk, S. ve Pench, L. (2010), "EU Fiscal Consolidation after The Financial Crisis Lessons from Past Experiences", European Commission Economic Papers, 418, 1-45.

Catao, L. A. ve Terrones, M. E. (2005), "Fiscal Deficits and Inflation", Journal of Monetary Economics, 52(3), 529-554.

Cherif, R. ve Hasanov, F. (2012), "Public Debt Dynamics: The Effects of Austerity, Inflation, and Growth Shocks", IMF Working Paper, 12(30), 1-26.

Çetin, A. (2005), "Kamu Borçlarının Makroekonomik Etkileri: Ampirik Bir Analiz", Atatürk Üniversitesi İktisadi ve İdari Bilimler Dergisi, 19(1), 67-79.

Çetintaş, H. (2005), “Türkiye'de Bütçe Açıkları Enflasyonun Nedeni midir?”, Iktisat Işletme ve Finans, 20(4), 115-127.

Çoban, H. (2015), "Ekonomik Koordinasyon Bağlamında Enflasyon Hedeflemesi ve Mali Disiplin İlişkisi: Türkiye Örneği”, Sosyoekonomi, 23(26), 215-228.

Çoban, O., Doğanalp, N. ve Uysal, D. (2008), "Türkiye'de Kamu İç Borçlanmasının Makro Ekonomik Etkileri”, Selçuk Üniversitesi Sosyal Bilimler Enstitüsü Dergisi, 20, 245-255.

Demir, M. ve Sever, E. (2008), "Kamu İç Borçlanmasının Büyüme, Faiz ve Enflasyon Oranı Üzerindeki Etkileri”, Elektronik Sosyal Bilimler Dergisi, 7(25), 170-196.

Ejder, H.L.(2006), Türkiye'de Mali Disiplinin Sağlanması Açısından Kamu Harcamaları Stratejisi: 1980-2002 Dönemi Analizi, Yayınlanmamış Doktora Tezi, Gazi Üniversitesi Sosyal Bilimler Enstitüsü.

Erkam, S. ve Çetinkaya, M. (2014), "Budget Deficits and Inflation: Evidence From Turkey", The Macrotheme Review, 3(8), 12-22.

European Council (1997), Resolution of the European Council on the Stability and Growth Pact Amsterdam, 17 June 1997, Official Journal of the European Communities, C 236, 2 August 1997. https://publications.europa.eu/en/ publication-detail/-/publication/1409c2d7-2549-4e85-99a0-b262887b3a7b/ language-en (Erişim: 16.09.2017).

Giannaros, D. S. ve Kolluri, B. R. (1985), "Deficit Spending, Money, and Inflation: Some International Empirical Evidence", Journal of Macroeconomics, 7(3), 401-417

Greenspan, A. (1995), Budget Deficits and Debt: Issues and Options, Opening Remarks, 1-4. A symposium sponsored by the Federal Reserve Bank of 
Kansas City. https://www.kansascityfed.org/ publicat/sympos/1995/pdf/s95green.pdf (Erişim: 16.09.2017).

Hemming, R. (2003), "Policies to Promote Fiscal Discipline", IMF Fiscal Affairs Department, 2, 1-19.

İpek, E. ve Akar, S. (2016), "Bütçe Açı̆̆ı ve Enflasyon Arasındaki İlişki: Türkiye İçin Ampirik Bir Analiz", Marmara Üniversitesi İktisadi ve İdari Bilimler Dergisi, 38 (2), 167-189.

Kalayci Ş., Aytemiz L. ve Helhel, Y. (2014), "İç Borç, Faiz, Enflasyon ve Üretim Etkileşimleri: Türkiye Örneği”, İktisat İsletme ve Finans Dergisi, 19, 80-87.

Kumar, M.S., Leigh, D. ve Plekhanov, A. (2007), "Fiscal Adjustments: Determinants and Macroeconomic Consequences", IMF Working Paper, 07(178), 1-40.

Lee, J. ve Strazicich, M.C. (2004), "Minimum LM Unit Root Test with One Structural Break", Department of Economics, Appalachian State University, Boone, North Carolina, Working Paper 04(17), 1-15. http://econ.appstate.edu/RePEc/pdf/wp0417.pdf (Erişim: 26.07.2017).

Lee, J. ve Strazicich, M.C. (2013), "Minimum LM Unit Root Test with One Structural Break", Economics Bulletin, 33(4), 2483-2492.

Leigh, D., Devries, P., Freedman, C., Guajardo, J., Laxton, D. ve Pescatori, A. (2010). Will it hurt? Macroeconomic effects of fiscal consolidation. In World $\begin{array}{lll}\text { Economic Outlook, IMF, 93-124. } & \text {. }\end{array}$ https://www.imf.org/external/pubs/ft/weo/2010/02/pdf/ c3.pdf (Erişim: 24.07.2017).

Metin, K. (1998), "The relationship between inflation and the budget deficit in Turkey”, Journal of Business \& Economic Statistics, 16(4), 412-422.

Molnar, M., (2012), "Fiscal Consolidation, Part 5. What Factors Determine The Success of Consolidation Efforts?", OECD Economics Department Working Papers, 936, 1-29. http://dx.doi.org/10.1787/5k9h28mzp57h-en1-29 (Erişim: 21.07.2017).

Nguyen, B. V. (2015), "Effects of Fiscal Deficit and Money M2 Supply on Inflation: Evidence from Selected Economies of Asia", Journal of Economics, Finance and Administrative Science, 20, 49-53.

Oğuz, Şebnem (2010), Türkiye'de Enflasyon Sürekliliğinin Analiz: Tarihsel Trend Ve Tüfe Alt Gruplarındaki Farklılaşması, Uzmanlık Yeterlilik Tezi, Türkiye Cumhuriyet Merkez Bankası İletişim ve Dış İlişkiler Genel Müdürlüğü. 
Oladipo, S. O. ve Akinbobola, T. O. (2011), "Budget Deficit and inflation in Nigeria: A Causal Relationship", Journal of Emerging Trends in Economics and Management Sciences, 2(1), 1-8.

Perron, P. (1989), "The Great Crash, the Oil Price Shock, and the Unit Root Hypothesis", Econometrica, 57(6), 1361-1401.

Sargent, T.J. ve Wallace, N. (1981), "Some Unpleasant Monetarist Arithmetic", Federal Reserve Bank of Minneapolis Quarterly Review, Fall, 1-18.

Susam, Nazan (2009), Türkiye'de Uygulanan Maliye Politikaları 1923-2008, 1. Baskı, İstanbul: Derin Yayınları.

Şahin, Hüseyin (2011), Türkiye Ekonomisi, Yenilenmiş 11. Baskı, Bursa: Ezgi Kitapevi Yayınları.

Toda, H. Y. ve Yamamoto, T. (1995), "Statistical Inference in Vector Autoregressions with Possibly İntegrated Processes", Journal of Econometrics, 66, 225-250.

Tüleykan, H. (2016), "Faiz Dışı Fazla ve Bazı Bütçe Verileri Arasında Nedensellik İlişkisi”, Çankırı Karatekin Üniversitesi Sosyal Bilimler Enstitüsü Dergisi, 7 (1), 301-322.

Ulusoy, A. (2014), Devlet Borçlanması, 8. Bask1, Trabzon: Aksakal Kitapevi.

Ulusoy, A. ve Erdem, H. F. (2014), "İç Borçlanma ve Enflasyon Etkileşimi: Türkiye Örneği”, Yönetim ve Ekonomi Araştırmaları Dergisi, 12(22), 122-135.

Vieira, Carlos (2000), Are Fiscal deficits inflationary? Evidence for the EU, Economic Research Paper No. 00/7, 1-16. http://citeseerx.ist.psu.edu/viewdoc/download? doi=10.1.1.35.1003\&rep= rep1\&type=pdf (Erişim: 09.16.2017)

Yamak, R. ve Korkmaz, A. (2005), "Reel Döviz Kuru ve Dış Ticaret Dengesi İlişkisi”, Ekonometri ve İstatistik e-Dergisi, (2), 16-38.

Yien, L. C., Abdullah, H. ve Azam, M. (2017), "Granger Causality Analysis between Inflation, Debt and Exchange Rate: Evidence from Malaysia", International Journal of Academic Research in Accounting, Finance and Management Sciences, 7(1), 189-196.

Zivot, E. ve Andrews, D. W. K. (1992), "Further Evidence on the Great Crash, the Oil-Price Shock, and the Unit-Root Hypothesis", Journal of Business \& Economic Statistics, 10(3), 251-270. 